\title{
PENGARUH PEMBELAJARAN DARING DAN FAKTOR LINGKUNGAN TERHADAP MOTIVASI BELAJAR TARUNA POLITEKNIK ILMU PELAYARAN SEMARANG
}

\author{
Andy Wahyu Hermanto $\circledast^{1)}$, M. Imroni Mubin $\circledast^{2)}$, Achmad Ridwan $\circledast^{3)}$, dan Dewi Kartika S. $\left(^{4)}\right.$ \\ ${ }^{1,3}$ Teknika, Politeknik Ilmu Pelayaran Semarang \\ ${ }^{2,4}$ Nautika, Politeknik Ilmu Pelayaran Semarang \\ 1,2,3,4 Jl. Singosari 2a Semarang, 50242 \\ E-mail : andy@pip-semarang.ac.id ${ }^{1}$, imroni@pip-semarang.ac.id ${ }^{2}$, ridwannahmad50@gmail.com ${ }^{3)}$, \\ dewi.kartika3008@gmail.com ${ }^{4)}$.
}

\begin{abstract}
ABSTRAK
Politeknik Ilmu Pelayaran (PIP) Semarang telah menerapkan sistem pembelajaran daring sejak pemerintah menetapkan kebijakan lockdown untuk mencegah penyebaran virus Covid-19 di Negara ini. Berdasarkan hasil observasi awal menunjukkan bahwa pembelajaran daring saat ini masih mengalami beberapa kendala, antara lain : Pemahaman taruna terkait materi yang diberikan dosen masih kurang, efektifitas pembelajaran masih kurang efektif, Faktor lingkungan yang kurang mendukung, kurangnya motivasi belajar taruna terhadap pembelajaran daring. Berdasarkan fenomena tersebut, maka tujuan dari penelitian ini adalah Untuk menganalisa pengaruh Pembelajaran Daring dan Faktor Lingkungan terhadap Motivasi Belajar Taruna PIP Semarang. Metode penelitian yang digunakan pada penelitian ini adalah Kuantitatif dengan pendekatan deskriptif. Populasi dalam penelitian ini adalah Taruna Taruni Semester 3 dan 8 dengan jumlah 492. Dengan menggunakan rumus Slovin maka jumlah sampel pada penelitian ini adalah 233 Taruna. Teknik pengambilan sampel dengan menggunakan kuesioner melalui Google form. Teknik analisis data menggunakan program SPSS versi 21. Berdasarkan hasil analisis dan pengolahan data angket disimpulkan bahwa Pembelajaran Daring berpengaruh signifikan terhadap Motivasi Belajar Taruna, dengan nilai signifikansi 0,000. Ada beberapa faktor yang dapat mempengaruhi pembelajaran daring untuk meningkatkan motivasi belajar taruna, yaitu faktor teknis, proses pembelajaran dan dukungan kampus PIP Semarang dalam menyelenggarakan pembelajaran daring. Faktor Lingkungan berpengaruh signifikan terhadap Motivasi Belajar Taruna, dengan nilai signifikansi 0,000. Beberapa faktor yang berpengaruh pada lingkungan keluarga yang dapat meningkatkan Motivasi Belajar Taruna, antara lain : Cara orang tua mendidik, relasi antar anggota keluarga, suasana rumah, keadaan ekonomi keluarga, pengertian orang tua dan latar belakang kebudayaan.
\end{abstract}

Kata Kunci: Pembelajaran Daring, Faktor Lingkungan, Motivasi Belajar, Taruna

\section{PENDAHULUAN}

Covid-19 adalah penyakit menular yang disebabkan oleh jenis coronavirus yang baru ditemukan. Walaupun lebih banyak menyerang ke lansia, virus ini sebenarnya bisa juga menyerang siapa saja, mulai dari bayi, anakanak, hingga orang dewasa. Virus corona ini bisa menyebabkan gangguan ringan pada sistem pernapasan, infeksi paru-paru yang berat, hingga kematian.

Hal tersebut membuat beberapa negara menetapkan kebijakan untuk memberlakukan lockdown dalam rangka mencegah penyebaran virus corona. Di Indonesia sendiri, diberlakukan kebijakan Pembatasan Sosial Berskala Besar (PSBB) untuk menekan penyebaran virus ini. Karena Indonesia sedang melakukan PSBB, maka semua kegiatan yang dilakukan di luar rumah harus dihentikan sampai pandemi ini mereda.

Beberapa pemerintah daerah memutuskan menerapkan kebijakan untuk meliburkan siswa dan mulai menerapkan metode belajar dengan sistem daring (dalam jaringan) atau online. Kebijakan pemerintah ini mulai efektif diberlakukan di beberapa wilayah provinsi di Indonesia pada hari Senin, 16 Maret 2020 yang juga diikuti oleh wilayah-wilayah provinsi lainnya.

Sistem pembelajaran daring (dalam jaringan) merupakan sistem pembelajaran tanpa tatap muka secara langsung antara guru dan siswa tetapi dilakukan melalui online yang menggunakan jaringan internet. Guru harus memastikan kegiatan belajar mengajar tetap berjalan, meskipun siswa berada di rumah. Solusinya, guru dituntut dapat mendesain media pembelajaran sebagai inovasi dengan memanfaatkan media daring (online). (Mather, M., \& Sarkans, A. 2018)

Berdasarkan hasil observasi awal yang kami lakukan mulai tanggal 16 s/d 18 Februari 2021 terhadap taruna/i PIP Semarang semester $1 \mathrm{~s} / \mathrm{d}$ semester 8 , melalui kuesioner online dari Google form, maka didapatkan data bahwa tingkat pemahaman terhadap materi yang diberikan Dosen adalah sebagai berikut : $52 \%$ responden menyatakan bahwa Kurang Paham, 35\% Paham, 11\% sangat paham, dan $2 \%$ tidak paham.

Efektifitas pembelajaran daring yang dilaksanakan adalah $47 \%$ responden taruna menyatakan pembelajaran 
daring kurang efektif, $40 \%$ responden menyatakan efektif, $11 \%$ responden menyatakan sangat efektif, dan $2 \%$ menyatakan tidak efektif.

Faktor lingkungan, menyatakan bahwa $42 \%$ responden menyatakan kurang mendukung, 37\% menyatakan mendukung, $17 \%$ menyatakan sangat mendukung, dan $4 \%$ menyatakan tidak mendukung.

Motivasi belajar didapatkan data bahwa $44 \%$ Responden atau taruna menyatakan bahwa kurang setuju pembelajaran daring dapat meningkatkan motivasi belajar, 38\% menyatakan setuju, $14 \%$ menyatakan sangat setuju, dan $4 \%$ menyatakan tidak setuju.

Tingkat kemudahan atau kelancaran mengikuti pembelajaran daring, diperoleh data bahwa $44 \%$ responden atau taruna menyatakan bahwa kurang lancar dalam mengikuti pembelajaran daring, 37\% menyatakan lancar, $17 \%$ menyatakan sangat lancar, dan $2 \%$ menyatakan tidak lancar

Dengan demikian dapat disimpulkan bahwa pembelajaran daring saat ini masih mengalami beberapa kendala, antara lain : Pemahaman taruna terkait materi yang diberikan dosen masih kurang, efektifitas pembelajaran masih kurang efektif, Faktor lingkungan yang kurang mendukung, kurangnya motivasi belajar taruna terhadap pembelajaran daring (Mulyasa. 2013).

Penelitian dengan judul Analisis Motivasi Belajar Mahasiswa dengan Sistem Pembelajaran Daring Selama Masa Pandemi Covid-19. Hasil penelitian diperoleh temuan bahwa pelaksanaan sistem pembelajaran secara daring berpengaruh positif terhadap motivasi belajar mahasiswa selama masa Pandemi Covid-19 dan motivasi belajar mahasiswa pada MK Statistik dipengaruhi oleh sistem pembelajaran daring yang (Sur, W. A. A., Hasanah, M., \& Mustofa, M. R. 2020)

Judul penelitiannya Pengaruh Motivasi Belajar dan Lingkungan Belajar Terhadap Hasil Belajar Mata Pelajaran Ekonomi Siswa Saat Pembelajaran Daring. Metode penelitian yang digunakan menggunakan metode kuantitatif. Hasil penelitiannya yaitu menunjukkan adanya pengaruh positif dan signifikan motivasi belajar dan lingkungan belajar terhadap hasil belajar siswa (Pratama, H. J., \& Ghofur, M. A., 2021)

Penelitian dengan judul Motivasi Belajar Mahasiswa Pada Pembelajaran Daring Selama Pandemic Covid-19. Hasil dari penelitian menyatakan bahwa motivasi belajar mahasiswa semester 6 program studi pendidikan guru sekolah dasar di Universitas Kuningan sangat baik, hal itu didapatkan dari skor persentase motivasi tersebut yang berjumlah $80,27 \%$. Penelitian ini dapat menjadi evaluasi berbagai pihak dalam menyelenggarakan pembelajaran daring di perguruan tinggi terutama yang melibatkan motivasi di dalamnya, penelitian ini juga diharapkan dapat menjadi bahan kajian bagi peneliti lain dalam menganalisis dan mengembangkan motivasi belajar mahasiswa dalam pembelajaran daring pada masa darurat di perguruan tinggi (Yani Fitriyani, dkk, 2016)

Penelitian dengan judul Efektifitas Pembelajaran Berbasis Daring: Sebuah Bukti Pada Pembelajaran
Bahasa Inggris. Menyatakan bahwa ada perbedaan kemampuan pemahaman mahasiswa terhadap teks berbahasa Inggris antara sebelum dan sesudah penggunaan web blog. Dalam hal ini, pembelajaran daring perbantuan web blog tersebut memberikan pengaruh positif terhadap peningkatan kemampuan membaca bahasa Inggris mahasiswa (Nurul Lailatul Khusniyah dkk, 2019)

Penelitian dengan judul Pengaruh Pembelajaran Daring Terhadap Minat Belajar Mahasiswa Pada Masa Pandemic Covid-19. Menyatakan bahwa sikap penggunaan internet, persepsi, pengalaman, kondisi finansial berpengaruh signifikan terhadap minat belajar mahasiswa. Sedangkan kemampuan belajar mandiri tidak memberikan pengaruh yang signifikan terhadap minat belajar mahasiswa selama perkuliahan daring (Nurul Lailatul Khusniyah dkk, 2019)

\section{RUANG LINGKUP}

Ruang lingkup penelitian ini adalah untuk menganalisis pengaruh pembelajaran daring dan pengaruh faktor lingkungan terhadap motivasi belajar taruna PIP Semarang. Penelitian ini dilaksanakan di Kampus Politeknik Ilmu Pelayaran Semarang dengan responden adalah taruna taruni yang aktif belajar.

Hasil penelitian ini diharapkan dapat menguatkan teori Pembelajaran Daring dalam implementasinya terhadap Motivasi Belajar Taruna di PIP Semarang. Pada perspektif akademis, penelitian ini akan menghasilkan sintesis mengenai Tingkat Pengaruh Pembelajaran Daring dan Faktor Lingkungan terhadap Motivasi Belajar Taruna Politeknik Ilmu Pelayaran (PIP) Semarang, sebagai sumbangan teoretis bagi perkembangan kajian ilmu manajemen kependidikan

\section{BAHAN DAN METODE}

Beberapa pustaka yang terkait dengan penelitian ini serta metode penelitian yang digunakan adalah sebagai berikut:

\subsection{Kerangka Teoretis}

Pembelajaran daring merupakan sebuah inovasi pendidikan yang melibatkan unsur teknologi informasi dalam pembelajaran. Pembelajaran daring merupakan sistem pendidikan jarak jauh dengan sekumpulan metode pengajaran dimana terdapat aktivitas pengajaran yang dilaksanakan secara terpisah dari aktivitas belajar (Mustofa, dkk, 2019).

Lingkungan adalah segala sesuatu yang ada di alam sekitar yang memiliki makna atau pengaruh tertentu kepada individu (Pratama, A, P. 2021). Lingkungan belajar yang paling dekat dengan peserta didik adalah lingkungan keluarga. Lingkungan keluarga adalah lingkungan yang berada di sekitar individu yang terdiri dari sekelompok sosial kecil yang mempunyai hubungan sedarah dimana lingkungan tersebut merupakan lingkungan pendidikan yang pertama dan utama karena sebelum manusia mengenal lembaga pendidikan yang 
lain, lembaga inilah yang pertama ada. Pendidikan keluarga dikatakan sebagai lembaga pendidikan yang utama karena di dalam lingkungan ini segenap potensi yang dimiliki individu terbentuk dan sebagian dikembangkan. Keluarga merupakan lembaga yang paling penting dalam proses sosialisasi seorang anak, karena keluarga lah yang memberikan setiap individu pengaruh akan menjadi apakah individu selanjutnya, apakah individu yang baik atau individu yang buruk (Basri, Hasan. 2013)

Motivasi adalah suatu usaha yang disadari untuk menggerakkan, mengarahkan dan menjaga tingkah laku seseorang agar ia terdorong untuk bertindak melakukan sesuatu sehingga mencapai hasil atau tujuan tertentu. Motivasi merupakan daya penggerak yang menjadi aktif atau dapat juga dikatakan sebagai serangkaian usaha untuk menyediakan kondisi-kondisi tertentu, sehingga seseorang mau dan ingin melakukan sesuatu. Motivasi sangat penting untuk membangkitkan semangat siswa dalam kegiatan pembelajaran di sekolah. Motivasi adalah seluruh faktor yang ada pada diri seseorang yang mendorongnya untuk melakukan suatu perbuatan, dimana dalam dunia pendidikan motivasi tersebut merupakan kekuatan atau dorongan yang ada pada diri peserta didik untuk melaksanakan kegiatan belajar dalam rangka mencapai tujuan pendidikan (Suyono dan Hariyanto. 2011).

\subsection{Metode Penelitian}

Dalam penelitian ini menggunakan pendekatan kuantitatif "pendekatan kuantitatif adalah pengukuran data kuantitatif dan statistik objektif melalui perhitungan ilmiah berasal dari sampel orang-orang atau penduduk yang diminta menjawab atas sejumlah pertanyaan tentang survey untuk menentukan frekuensi dan persentase tanggapan mereka" (Cresweel, 2016).

Populasi dari penelitian ini adalah seluruh Taruna Program Studi Nautika, Teknika dan TALK Politeknik Ilmu Pelayaran (PIP) Semarang semester 3 dan 8, dengan jumlah taruna adalah 492 taruna. Jumlah sampel yang diambil berdasarkan rumus Slovin. Rumus Slovin adalah sebuah rumus atau formula untuk menghitung jumlah sampel minimal apabila perilaku dari sebuah populasi tidak diketahui secara pasti. Secara Matematis, Rumus Slovin yang kita gunakan untuk menentukan jumlah sampel pada rumus (1).

$$
\mathrm{n}=\mathrm{N} /\left(1+\mathrm{N} \cdot(\mathrm{e})^{2}\right)
$$

Keterangan :

$\mathrm{n}=$ Jumlah Sampel

$\mathrm{N}=$ Jumlah Total Populasi

$\mathrm{e}=$ Batas Toleransi Error

(Catatan : Rumus Slovin ini dikutip dari buku Wiratna (Sujarweni, 2014))

Berdasarkan notasi rumus besar sampel penelitian minimal oleh Slovin pada rumus (1), maka apabila kita memiliki 492 taruna dalam sebuah populasi, kita bisa tentukan minimal sampel yang akan diteliti. Margin of error yang ditetapkan adalah 5\% atau 0,05.

Perhitungannya rumus (2).

$\mathrm{n}=\mathrm{N} /\left(1+\left(\mathrm{N} x \mathrm{e}^{2}\right)\right)$

Sehingga: $\mathrm{n}=492 /\left(1+\left(492 \times 0,05^{2}\right)\right)$

$\mathrm{n}=492 /(1+(492 \times 0,0025))$

$\mathrm{n}=492 /(1+1,23)$

$\mathrm{n}=492 / 2,23$

$\mathrm{n}=220,627$

Apabila dibulatkan maka besar sampel minimal dari 492 populasi pada margin of error 5\% adalah sebesar 221.

Berdasarkan ketentuan tersebut, maka dalam penelitian ini jumlah sampel yang diambil adalah seperti terlihat pada tabel 1 .

Tabel 1. Jumlah Populasi Dan Sampel Responden

\begin{tabular}{|c|c|c|c|}
\hline No & Kelas & $\begin{array}{l}\text { Jumlah } \\
\text { Taruna }\end{array}$ & $\begin{array}{l}\text { Jumlah } \\
\text { Sampel }\end{array}$ \\
\hline 1 & N III A & 24 & \multirow{19}{*}{157} \\
\hline 2 & N III B & 24 & \\
\hline 3 & N III C & 23 & \\
\hline 4 & N III D & 25 & \\
\hline 5 & N III E & 18 & \\
\hline 6 & N III F & 18 & \\
\hline 7 & N III G & 17 & \\
\hline 8 & N III H & 17 & \\
\hline 9 & T III A & 24 & \\
\hline 10 & T III B & 24 & \\
\hline 11 & T III C & 24 & \\
\hline 12 & T III D & 23 & \\
\hline 13 & T III E & 16 & \\
\hline 14 & T III F & 17 & \\
\hline 15 & T III G & 15 & \\
\hline 16 & K III A & 24 & \\
\hline 17 & K III B & 25 & \\
\hline 18 & K III C & 27 & \\
\hline 19 & K III D & 27 & \\
\hline 20 & N VII A & 22 & \multirow{4}{*}{76} \\
\hline 21 & N VII B & 22 & \\
\hline 22 & T VIII A & 18 & \\
\hline 23 & T VIII B & 18 & \\
\hline \multicolumn{2}{|c|}{ TOTAL } & 492 & 233 \\
\hline
\end{tabular}

Sumber : Data Penelitian 2021

\subsection{Kerangka Pikir Penelitian}

Kerangka pikir penelitian yang akan dianalisis dalam penelitian ini dapat dilihat pada Gambar 1. 


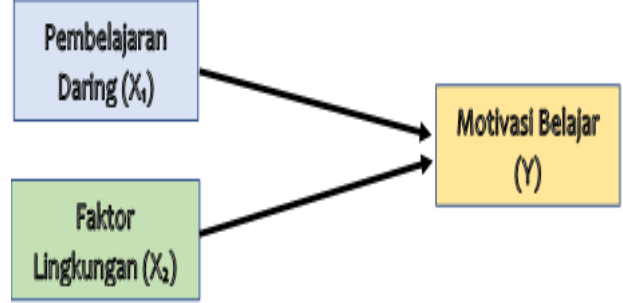

Gambar 1. Kerangka Pikir Penelitian

Pembelajaran daring atau online yang dilaksanakan di PIP Semarang saat ini sangat mempengaruhi motivasi belajar taruna taruni. Hal ini tidak terlepas dari fasilitas pembelajaran yang tersedia. Bila fasilitas pembelajaran daring bagus atau baik, maka taruna taruni tidak akan mengalami kendala dalam melaksanakan perkuliahan atau pembelajaran secara daring. Di samping itu faktor lingkungan juga sangat berpengaruh terhadap proses pembelajaran daring. Faktor lingkungan yang sangat berpengaruh adalah Lingkungan Keluarga. Karena pembelajaran daring dilakukan di tempat tinggal masingmasing, maka lingkungan keluarga sangatlah berpengaruh terhadap kelancaran dan kemudahan pembelajaran daring. Dengan adanya lingkungan keluarga yang kondusif, maka pembelajaran daring akan terlaksana dengan baik, sehingga dapat meningkatkan motivasi belajar taruna taruni PIP Semarang.

\subsection{Variabel Penelitian}

Variabel penelitian yang digunakan dalam penelitian ini terdiri dari variabel independen dan variabel dependen. Variabel independen terdiri dari variabel pembelajaran (X1) dan variabel Faktor Lingkungan (X2), sedangkan variabel dependen adalah Motivasi Belajar Taruna (Y). Berikut adalah penjelasan dari masingmasing variabel:

1. Variabel Pembelajaran Daring $\left(\mathrm{X}_{1}\right)$, adalah pembelajaran yang dilakukan secara virtual dengan menggunakan aplikasi virtual yang tersedia. Pembelajaran Daring terdiri dari indikator : Faktor Teknis $\left(\mathrm{X}_{1.1}\right)$, Proses Pembelajaran $\left(\mathrm{X}_{1.2}\right)$, Dukungan Kampus PIP Semarang $\left(\mathrm{X}_{1.3}\right)$.

2. Variabel Faktor Lingkungan $\left(X_{2}\right)$, dalam penelitian ini faktor lingkungan yang dimaksud yaitu Lingkungan Keluarga. Lingkungan Keluarga adalah lingkungan yang berada di sekitar individu yang terdiri dari sekelompok sosial kecil yang mempunyai hubungan sedarah dimana lingkungan tersebut merupakan lingkungan pendidikan yang pertama dan utama karena sebelum manusia mengenal lembaga pendidikan yang lain, lembaga inilah yang pertama ada. Dengan indikator : Cara Orang Tua Mendidik $\left(\mathrm{X}_{2.1}\right)$, Relasi antar anggota keluarga $\left(\mathrm{X}_{2.2}\right)$, Suasana Rumah $\left(\mathrm{X}_{2.3}\right)$, Keadaan Ekonomi Keluarga $\left(\mathrm{X}_{2.4}\right)$, Pengertian Orang Tua $\left(\mathrm{X}_{2,5}\right)$, Latar Belakang Kebudayaan $\left(\mathrm{X}_{2,6}\right)$.

3. Variabel Dependen atau endogen dalam penelitian ini adalah Motivasi Belajar Taruna (Y) PIP
Semarang Prodi Nautika, Teknika dan TALK dengan indikator : Dorongan Mencapai Sesuatu $\left(\mathrm{Y}_{2.1}\right)$, Komitmen $\left(\mathrm{Y}_{2.2}\right)$, Inisiatif $\left(\mathrm{Y}_{2.3}\right)$, Optimis $\left(\mathrm{Y}_{2,4}\right)$.

\subsection{Instrumen Pengumpulan Data}

Dalam penelitian ini, variabel $\mathrm{X}$ diukur oleh instrumen pengukur dalam bentuk kuesioner yang memenuhi pernyataan-pernyataan tipe skala likert. Skala likert. Skala Likert digunakan untuk mengukur sikap, pendapat dan persepsi seseorang atau sekelompok orang tentang fenomena sosial (Puspitaningtyas N, D, dkk. 2020). Untuk setiap pilihan jawaban diberi skor, maka responden harus menggambarkan, mendukung pernyataan, untuk digunakan jawaban yang dipilih. Dengan skala Likert, maka variabel yang akan diukur dijabarkan menjadi indikator variabel. Kemudian indikator tersebut dijadikan sebagai titik tolak ukur menyusun item-item instrumen yang dapat berupa pertanyaan atau pernyataan (Sugiyono, 2018). Skala likert yang digunakan pada penelitian ini menggunakan 4 skor, yaitu 1 (satu) sampai dengan 4 (empat).

Pada Tanggal 15 September 2021 telah dilaksanakan pengambilan sampel kuesioner kepada Responden atau taruna untuk dilakukan uji Validitas dan Reliabilitas dari Kuesioner. Jumlah Responden atau Taruna untuk uji sampel adalah 30 Taruna, dengan jumlah butir pertanyaan adalah 61. Pengambilan sampel dilakukan melalui Google Form, dengan periode pengambilan sampel pada tanggal 15 September 2021. Berikut hasil dari Uji Validitas data:

1. Variabel Pembelajaran Daring $\left(\mathrm{X}_{1}\right)$

Variabel Pembelajaran Daring $\left(\mathrm{X}_{1}\right)$ terdiri dari 19 butir pernyataan. Berdasarkan hasil pengolahan data sampel dengan menggunakan SPSS ver.21, maka dapat disimpulkan bahwa butir pernyataan nomor 1, 8, 13, 15, dan 16 Tidak Valid karena nilai rHitung < dari rTabel atau kurang dari $\mathbf{0 , 3 4 9 4}$, sedangkan yang lainnya dinyatakan Valid karena memiliki nilai rHitung > dari rTabel.

2. Variabel Faktor Lingkungan $\left(\mathrm{X}_{2}\right)$ Variabel Faktor Lingkungan $\left(\mathrm{X}_{2}\right)$ terdiri dari 19 butir pernyataan. Berdasarkan hasil pengolahan data sampel dengan menggunakan SPSS ver.21, maka dapat disimpulkan bahwa butir pernyataan nomor 21 dan 28 Tidak Valid karena nilai rHitung $<$ dari rTabel atau kurang dari $\mathbf{0 , 3 4 9 4}$, sedangkan yang lainnya dinyatakan Valid karena memiliki nilai rHitung $>$ dari rTabel.

3. Variabel Motivasi Belajar Taruna (Y) Variabel Motivasi Belajar Taruna (Y) terdiri dari 23 butir pernyataan. Berdasarkan hasil pengolahan data sampel dengan menggunakan SPSS ver.21, maka dapat disimpulkan bahwa seluruh butir pernyataan dinyatakan valid karena memiliki nilai rHitung > dari rTabel.

Sedangkan hasil Uji Reliabilitas diperoleh data sebagai berikut: 
1. Variabel Pembelajaran Daring $\left(\mathrm{X}_{1}\right)$

Berdasarkan hasil pengolahan data dengan menggunakan SPSS ver 21, maka didapatkan nilai Cronbach's Alpha dari variabel Pembelajaran Daring (X1) adalah 0,794. Sehingga dengan demikian variabel X1 dinyatakan Reliabel.

2. Variabel Faktor Lingkungan $\left(\mathrm{X}_{2}\right)$

Berdasarkan hasil pengolahan data dengan menggunakan SPSS ver 21, maka didapatkan nilai Cronbach's Alpha dari variabel Faktor Lingkungan $\left(\mathrm{X}_{2}\right)$ adalah 0,790. Sehingga dengan demikian variabel $\mathrm{X}_{2}$ dinyatakan Reliabel

3. Variabel Motivasi Belajar Taruna (Y)

Berdasarkan hasil pengolahan data dengan menggunakan SPSS ver 21, maka didapatkan nilai Cronbach's Alpha dari variabel Motivasi Belajar Taruna (Y) adalah 0,974. Sehingga dengan demikian variabel Y dinyatakan Reliabel

\subsection{Teknik Analisis Data}

Teknik Analisis data pada penelitian ini menggunakan Analisis Regresi. Analisis Regresi dalam penelitian ini digunakan untuk menganalisis pengaruh langsung variabel independen terhadap variabel dependen. Yang dimaksud variabel independen dalam penelitian ini adalah Pembelajaran Daring dan Faktor Lingkungan (Cahyani, A. 2020). Sedangkan variabel dependen adalah Motivasi Belajar Taruna PIP Semarang. Perhitungan Regresi sederhana menggunakan perangkat SPSS-21.

\section{PEMBAHASAN}

Berdasarkan analisis data yang dilakukan dengan menggunakan program SPSS versi 2.1., maka dapat diperoleh data terkait dengan uji prasyarat atau uji asumsi klasik dari data responden. Di samping itu juga diperoleh data hasil uji regresi dari data responden. Hasil analisis dari rumusan masalah yang disampaikan pada pendahuluan.

\subsection{Hasil Uji Prasyarat atau Uji Asumsi Klasik Data Responden}

Data yang diperoleh dari responden akan dilakukan uji prasyarat sebelum dilakukan Uji Regresi Data. Uji prasyarat merupakan salah satu syarat dalam pengujian data hasil responden, yang meliputi Uji Normalitas, Uji Linieritas dan Uji Multikolinieritas Data. Hasil dari Uji prasyarat sebagai berikut:

1. Hasil Uji Normalitas

Berdasarkan hasil uji normalitas data dengan menggunakan SPSS ver.21, diperoleh hasil seperti Tabel 2, dasar pengambilan keputusan berdasarkan probabilitas atau signifikan. Jika probabilitas atau signifikan lebih besar dari 0,05 , maka data penelitian terdistribusi normal.
Tabel 2. Hasil Uji Normalitas Data

One-Sample Kolmogorov-Smirnov Test

\begin{tabular}{|cc|r|}
\hline & & \multicolumn{1}{|c|}{$\begin{array}{c}\text { Unstandardized } \\
\text { Residual }\end{array}$} \\
\hline \multicolumn{2}{|c|}{$\mathrm{N}$} & 233 \\
Normal $_{\text {Parameters }}^{\mathrm{a}, \mathrm{b}}$ & Mean &, 0000000 \\
& Std. & 7,09216282 \\
Most Extreme & Abviation &, 041 \\
Differences & Positive &, 041 \\
& Negative &,- 033 \\
Kolmogorov-Smirnov Z &, 622 \\
Asymp. Sig. (2-tailed) &, $\mathbf{8 3 4}$ \\
\hline
\end{tabular}

a. Test distribution is Normal.

b. Calculated from data.

Hasil uji normalitas data tabel 2. sesuai dengan tabel 2. menunjukkan bahwa nilai KolmogorovSmirnov residual data menunjukkan nilai sebesar 0,834 . Dengan demikian data hasil penelitian sudah terdistribusi Normal, karena nilai probabilitas atau signifikan nya lebih besar dari 0,05

2. Hasil Uji Linieritas

Uji Linieritas dilakukan untuk mengetahui bentuk hubungan antara variabel bebas dengan variabel terikat. Jika nilai Sig. linearity $>0,05$, maka terdapat hubungan yang linear antara variabel independen dengan variabel dependen. Jika nilai Sig. linearity $<0,05$, maka tidak terdapat hubungan yang linear antara variabel independen dengan variabel dependen. Hasil Uji Linieritas dapat dilihat pada Tabel 3.

Tabel 3. Hasil Uji Linieritas Data

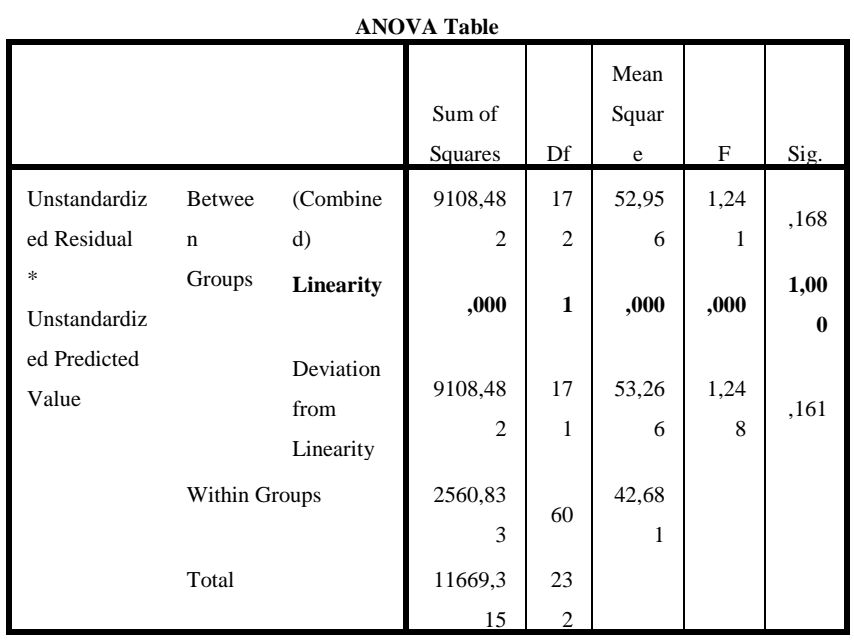

Berdasarkan hasil uji Linieritas data dengan menggunakan SPSS ver.21, diperoleh hasil seperti Tabel 3. Diketahui nilai Sig. Linearity lebih besar dari 0,05, yaitu 1,000. Maka dapat disimpulkan bahwa terdapat 
hubungan yang linear antara variabel independen dengan variabel dependen.

3. Hasil Uji Multikolinieritas

Uji Multikolinearitas adalah bagian dari uji asumsi klasik dalam analisis regresi linear berganda. Uji Multikolinearitas bertujuan untuk mengetahui apakah terjadi interkorelasi (hubungan yang kuat) antar variabel independen. Model regresi yang baik ditandai dengan tidak terjadinya interkorelasi antar variabel independen (tidak terjadi gejala multikolinearitas). Salah satu cara yang paling akurat untuk mendeteksi ada atau tidaknya gejala multikolinearitas ini adalah dengan menggunakan metode Tolerance dan VIF (Variance Inflation Factor). Dasar pengambil keputusan uji multikolinearitas adalah jika nilai Tolerance lebih besar dari > 0,10 maka artinya tidak terjadi multikolinearitas. Jika nilai VIF lebih kecil dari $<10,00$ maka artinya tidak terjadi multikolinearitas. Hasil perhitungan

Tabel 4. Hasil Uji Multikolinieritas Data

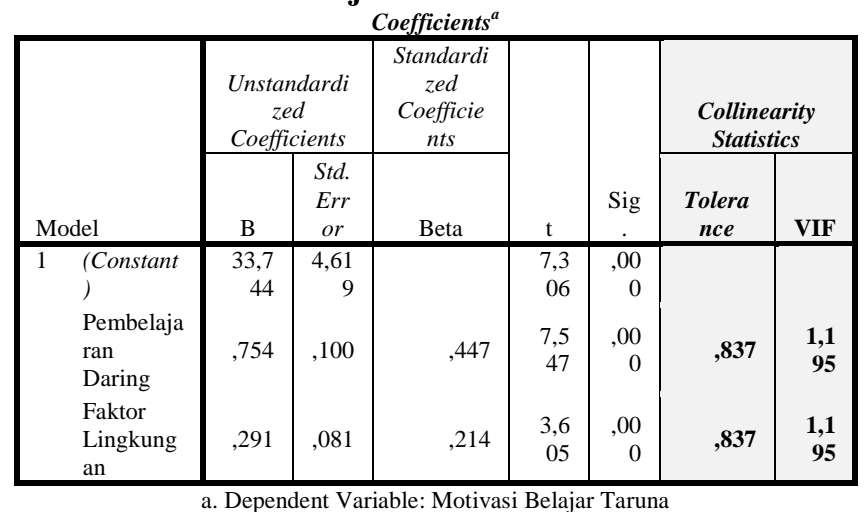

Berdasarkan hasil uji multikolinieritas data dengan menggunakan SPSS ver.21, diperoleh hasil seperti Tabel 4. Nilai Tolerance dari variabel Independen (Pembelajaran Daring dan Faktor Lingkungan) lebih besar dari > 0,10 dan nilai VIF lebih kecil dari < 10,00. Maka dapat disimpulkan bahwa data tidak terjadi masalah multikolinearitas.

\subsection{Hasil Analisis Regresi}

Berdasarkan hasil pengolahan data Regresi Linier Berganda dengan menggunakan program SPSS ver.21, maka diperoleh data pada tabel 5.
Tabel 5. Hasil Analisis Regresi

\begin{tabular}{|l|r|r|r|r|}
\hline & & & Model Summary \\
Model & $\mathrm{R}$ & $\mathrm{R}$ Square & $\begin{array}{c}\text { Adjusted R } \\
\text { Square }\end{array}$ & $\begin{array}{c}\text { Std. Error of } \\
\text { the Estimate }\end{array}$ \\
\hline 1 & $.568^{\mathrm{a}}$ &, 323 &, 317 & 7,123 \\
\hline
\end{tabular}

ANOVA $^{\mathrm{a}}$

\begin{tabular}{|c|c|c|c|c|c|}
\hline Model & $\begin{array}{l}\text { Sum of } \\
\text { Squares } \\
\end{array}$ & df & $\begin{array}{c}\text { Mean } \\
\text { Square } \\
\end{array}$ & $\mathrm{F}$ & Sig. \\
\hline 1 Regression & 5570,624 & 2 & 2785,312 & \multirow[t]{3}{*}{54,898} & \multirow[t]{3}{*}{$.000^{\mathrm{b}}$} \\
\hline Residual & 11669,315 & 230 & \multirow[t]{2}{*}{50,736} & & \\
\hline Total & 17239,940 & 232 & & & \\
\hline
\end{tabular}

b. Predictors: (Constant), Faktor Lingkungan, Pembelajaran Daring

\begin{tabular}{|c|c|c|c|c|c|}
\hline & & Coefficients & & & \\
\hline \multirow[b]{2}{*}{ Model } & \multicolumn{2}{|c|}{$\begin{array}{c}\text { Unstandardized } \\
\text { Coefficients }\end{array}$} & \multirow{2}{*}{$\begin{array}{c}\text { Standardized } \\
\text { Coefficients } \\
\text { Beta } \\
\end{array}$} & \multirow[b]{2}{*}{$\mathrm{t}$} & \multirow[b]{2}{*}{ Sig. } \\
\hline & $\mathrm{B}$ & Std. Error & & & \\
\hline 1 (Constant) & 33,744 & 4,619 & & 7,306 & ,000 \\
\hline $\begin{array}{l}\text { Pembelajaran } \\
\text { Daring }\end{array}$ & ,754 & , 100 & ,447 & 7,547 &, 000 \\
\hline $\begin{array}{l}\text { Faktor } \\
\text { Lingkungan }\end{array}$ & ,291 &, 081 & ,214 & 3,605 &, 000 \\
\hline
\end{tabular}

Interpretasi pembacaan output untuk proses uji hipotesis dapat diikuti dengan langkah sebagai berikut :

Model Regresi : $Y=\beta_{0}+\beta_{1} X_{1}+\beta_{2} X_{2}+\varepsilon$

1. Bentuk hipotesis uji model linier :

$\mathrm{H}_{0}: \beta=\left(\beta_{1}, \beta_{2}\right)=0$ (persamaan tak linier atau tidak ada relasi antara $\mathrm{X}_{1}, \mathrm{X}_{2}$, dan $\left.\mathrm{Y}\right)$

$\mathrm{H}_{1}: \beta=\left(\beta_{1}, \beta_{2}\right) \neq 0$ (persamaan adalah linier atau ada relasi $\mathrm{X}_{1}, \mathrm{X}_{2}$ dan $\mathrm{Y}$ )

2. Formulasi rancangan analisis: penaksir model linier $\mathrm{y}=\mathrm{a}+\mathrm{bx}_{1}+\mathrm{cx}_{2}$, dengan uji dua pihak, taraf signifikan $5 \%$.

Persamaan regresi berdasar sampel dibaca pada output coefficients: pada Unstandardized coefficient B : constant, Pembelajaran Daring $\left(\mathrm{X}_{1}\right)$, Faktor Lingkungan $\left(\mathrm{X}_{2}\right)$.

Diperoleh nilai $\mathrm{a}=33,744, \mathrm{~b}=0,754, \mathrm{c}=0,291$.

Jadi persamaan regresi:

$y=33,744+(0,754) X_{1}+(0,291) X_{2}$.

Kita akan uji nilai a, b, dan c tersebut.

Untuk menerima atau menolak hipotesis dibaca Tabel perhitungan distribusi $\mathrm{F}$ atau pada output tabel ANOVA : diperoleh nilai $\mathrm{F}=54,898$, sig $=$ 0,000 , tidak perlu dicocokkan dengan tabel $\mathrm{F}$, karena SPSS sudah memfasilitasi dengan nilai signifikan.

3. Hasil analisis:

Sig $=0,000=0 \%<5 \%$ berarti tolak $\mathrm{H}_{0}$ dan menerima $\mathrm{H}_{1}$. Jadi persamaan adalah linier atau $\mathrm{X}_{1}$ dan $\mathrm{X}_{2}$ secara bersama-sama mempunyai hubungan linier terhadap $\mathrm{Y}$ atau $\mathrm{X}_{1}$ dan $\mathrm{X}_{2}$ secara bersama-sama berpengaruh Positif 
terhadap Y. Oleh karena itu analisis dapat dilanjutkan ke proses melihat besar pengaruh dengan melihat nilai koefisien determinasi $\mathrm{R}^{2}$.

4. Interpretasi Hasil:

Nilai koefisien determinasi dapat dibaca pada nilai $\mathrm{R}$ square yakni pada output model summary:

Diperoleh nilai $\mathrm{R}$ square atau $\mathrm{R}^{2}=0,323=$ $32,1 \%$. Nilai tersebut menunjukkan bahwa variasi variabel Motivasi Belajar Taruna (Y) dapat dijelaskan oleh Pembelajaran Daring $\left(\mathrm{X}_{1}\right)$ dan Faktor Lingkungan $\left(\mathrm{X}_{2}\right)$ sebesar 32,3\%. Dengan kata lain variabel $\mathrm{X}_{1}$ dan $\mathrm{X}_{2}$ secara bersama-sama mempengaruhi variabel $\mathrm{Y}$ sebesar $32,3 \%$, masih ada $67,7 \%$ variabel $\mathrm{Y}$ dipengaruhi atau dapat diterangkan oleh variabel lain selain Pembelajaran Daring dan Faktor Lingkungan. Dengan menerima nya persamaan regresi $\mathrm{Y}_{1}=33,744+(0,754) X_{1}$. $(0,291) X_{2}$, maka dengan persamaan tersebut dapat dijadikan sebagai dasar memprediksi variabel dependen $\mathrm{Y}$ jika diketahui nilai variabel independen $X_{1}$ dan $X_{2}$. Misalkan skor Pembelajaran Daring 70 dan skor Faktor Lingkungan 75 maka hasil Motivasi Belajar Taruna tersebut dapat di taksir memiliki Motivasi sebesar 33,744 + (0,754)70 + $(0,291) 75=107,649$

Berdasarkan hasil analisis regresi yang telah disampaikan diatas, maka dapat dirumuskan sebagai berikut :

1. Pengaruh Pembelajaran Daring terhadap Motivasi Belajar Taruna

Hasil pengujian Hipotesis yang dilakukan membuktikan bahwa pengaruh Pembelajaran Daring terhadap Motivasi Belajar Taruna cukup kuat. Dari olah data analisis regresi sederhana menunjukkan bahwa pengaruh variabel Pembelajaran Daring terhadap Motivasi Belajar Taruna memiliki nilai signifikansi sebesar $0,000<$ 0,05 . Hal ini berarti bahwa semakin baik pelaksanaan pembelajaran daring yang dilakukan Taruna maka Semakin tinggi pula Motivasi Belajar Taruna.

Pembelajaran daring merupakan sistem pendidikan jarak jauh dengan sekumpulan metode pengajaran dimana terdapat aktivitas pengajaran yang dilaksanakan secara terpisah dari aktivitas belajar. Pembelajaran daring telah banyak dilakukan dalam konteks perguruan tinggi. Pembelajaran daring memberikan manfaat dalam membantu menyediakan akses belajar bagi semua orang, sehingga menghapus hambatan secara fisik sebagai faktor untuk belajar dalam ruang lingkup kelas. Bahkan hal tersebut dipandang sebagai sesuatu yang efektif untuk diterapkan khususnya dalam perguruan tinggi (Mustofa, dkk, 2019).

Pelaksanaan pembelajaran daring masuk dalam kategori cukup baik. Meskipun pembelajaran online cukup baik, sebagian besar mahasiswa menyatakan bahwa pelaksanaan eksperimen mengalami hambatan, kurang memahami penjelasan dosen serta sulit memahami rumus selama pembelajaran online, dan mengalami hambatan saat pembelajaran online karena keterbatasan Internet (Maria Goretta Sarahutu, 2020).

Pembelajaran daring merupakan solusi pembelajaran di era pandemi covid 19. Akan tetapi, tentu saja dalam pelaksanaan pembelajaran daring pasti banyak terdapat kesulitan yang dihadapi baik oleh guru maupun siswa. Hasil penelitian menyatakan bahwa siswa mendapat dukungan yang baik dari berbagai pihak dalam melaksanakan pembelajaran dalam jaringan. Namun, mayoritas siswa mengalami kendala terkait signal selama pembelajaran daring. Banyak siswa juga belum dapat menguasai aplikasi pembelajaran dengan baik sehingga akan berpengaruh pada proses pembelajaran. Selain itu, siswa menyatakan mengalami kesulitan berkomunikasi dengan guru dan lebih menyukai berdiskusi secara tatap muka serta siswa mengalami kesulitan dalam memahami materi apabila hanya bersumber dari buku (Nicky Dwi Puspitaningtyas, dkk, 2020)

Motivasi belajar mahasiswa semester 6 program studi pendidikan guru sekolah dasar di Universitas Kuningan sangat baik, hal itu didapatkan dari skor persentase motivasi tersebut yang berjumlah 80,27\%. Penelitian ini dapat menjadi evaluasi berbagai pihak dalam menyelenggarakan pembelajaran daring di perguruan tinggi terutama yang melibatkan motivasi di dalamnya, penelitian ini juga diharapkan dapat menjadi bahan kajian bagi peneliti lain dalam menganalisis dan mengembangkan motivasi belajar mahasiswa dalam pembelajaran daring pada masa darurat di perguruan tinggi (Yani Fitriyani' dkk, tahun 2020)

Dari hasil penelitian sebelumnya yang telah dilakukan oleh Maria Goretta dkk menyatakan bahwa pembelajaran daring yang dilaksanakan cukup baik. Demikian pula menurut Nicky Dwi $\mathrm{P}$, dkk menyatakan bahwa Pembelajaran daring merupakan solusi pembelajaran di era pandemi covid 19. Menurut Yani Fitriyani, dkk menyatakan bahwa dapat menjadi evaluasi berbagai pihak dalam menyelenggarakan pembelajaran daring di perguruan tinggi terutama yang melibatkan motivasi di dalamnya. Hasil yang sama juga didapatkan dari penelitian, 
bahwa pembelajaran daring berpengaruh signifikan terhadap motivasi belajar taruna. Banyak faktor yang dapat mempengaruhi tingkat keberhasilan dari pembelajaran daring. Faktor teknis merupakan salah satu yang sangat berpengaruh kegiatan pembelajaran daring. Faktor teknis bisa berasal dari internal dan eksternal. Faktor internal bisa berasal dari sumber daya manusia itu sendiri, misalnya kemampuan atau kecakapan mengoperasikan komputer atau internet, mahir atau terampil dalam mengakses internet, dan lain-lain. Sedangkan faktor eksternal dapat berupa gangguan teknis sinyal ataupun internet dari server atau provider. Bila sambungan internet tidak lancar, maka dapat mengganggu proses pembelajaran daring. Bila pembelajaran daring terganggu maka akan sangat berpengaruh terhadap motivasi belajar taruna. Motivasi belajar akan menurun bila pembelajaran daring tidak berjalan dengan lancar. Sebaliknya, jika pembelajaran daring berjalan lancar, maka motivasi belajar taruna juga akan meningkat (Jamil, S.H, dkk. 2020). Pembelajaran daring juga dapat dipengaruhi oleh proses pembelajaran, yang mana adanya interaksi antara dosen dengan taruna. Bila komunikasi antara dosen dengan taruna berjalan dengan baik, maka dapat dikatakan proses pembelajaran daring berjalan dengan baik, dengan demikian motivasi belajar taruna juga akan meningkat (Alessandro, B. 2018).. Tak kalah penting juga bahwa pembelajaran daring akan dapat terlaksana dengan baik jika didukung oleh pihak kampus PIP Semarang. Misalnya dengan menyediakan program e-Learning bagi taruna untuk pembelajaran daring. Dengan tersedianya eLearning bagi taruna untuk pembelajaran daring, maka proses pembelajaran dapat berjalan dengan baik.

2. Pengaruh Faktor Lingkungan terhadap Motivasi Belajar Taruna

Hasil pengujian Hipotesis yang dilakukan membuktikan bahwa pengaruh Faktor Lingkungan terhadap Motivasi Belajar Taruna cukup kuat. Dari olah data analisis regresi sederhana menunjukkan bahwa pengaruh variabel Faktor Lingkungan terhadap Motivasi Belajar Taruna memiliki nilai signifikansi sebesar $0,000<$ 0,05 . Hal ini berarti bahwa faktor lingkungan yang baik dapat mempengaruhi Motivasi Belajar Taruna. Faktor Lingkungan yang kondusif dan mendukung, maka akan dapat meningkatkan Motivasi Belajar Taruna.

Siswa yang belajar akan menerima pengaruh dari keluarga berupa cara orang tua mendidik, relasi antar anggota keluarga, suasana rumah, keadaan ekonomi keluarga, pengertian orang tua dan latar belakang kebudayaan. Bimbingan dan penyuluhan memegang peranan yang penting. Anak atau siswa yang mengalami kesukarankesukaran dalam belajar dapat ditolong dengan memberikan bimbingan belajar sebaik-baiknya. Tentu saja keterlibatan orang tua akan sangat mempengaruhi belajar anak. Orang tua dapat memberikan motivasi kepada anak-anaknya dengan berbagai macam cara, salah satunya adalah dengan memberikan fasilitas yang memadai sehingga anak-anaknya dapat belajar dengan baik sehingga hasil belajar pun akan optimal. Cara orang tua mendidik, relasi antar anggota keluarga, suasana rumah dan keadaan ekonomi keluarga, pengertian orang tua, dan latar belakang kebudayaan jelas akan memberikan pengaruh terhadap motivasi belajar siswa

Ada pengaruh positif lingkungan keluarga terhadap motivasi belajar siswa kelas XI IS di SMA Negeri 8 Purworejo sebesar 0,260 atau 26\%. Lingkungan keluarga siswa tergolong harmonis, meskipun pada indikator cara orang tua mendidik masih tergolong rendah, sehingga siswa kurang sadar akan pentingnya belajar karena tidak pernah diingatkan untuk belajar (Damayanti, R. 2011).

Lingkungan keluarga, motivasi wirausaha, kepribadian wirausaha berpengaruh secara langsung maupun tidak langsung melalui selfefficacy sebagai mediasi terhadap minat wirausaha siswa kelas XI SMK Negeri Salatiga (Agus Kurniawan, dkk, 2016).

Lingkungan keluarga berpengaruh positif dan signifikan terhadap hasil belajar siswa dengan kontribusi efektif (R2) sebesar 4,1\%. Kompetensi guru, motivasi belajar, dan lingkungan keluarga secara bersama-sama berpengaruh positif dan signifikan terhadap hasil belajar siswa dengan kontribusi efektif (R2 ) sebesar 43,1\%. Hal ini berarti variabel kompetensi guru, motivasi belajar, dan lingkungan keluarga mempengaruhi variabel hasil belajar siswa secara terpisah maupun secara bersama-sama (Sutardi, dkk, tahun 2016)

Dari hasil penelitian sebelumnya yang telah dilakukan oleh Rasista Damayanti menyatakan bahwa faktor lingkungan keluarga berpengaruh positif terhadap motivasi belajar siswa. Demikian pula menurut Agus Kurniawan, dkk menyatakan bahwa faktor lingkungan keluarga berpengaruh positif terhadap motivasi wirausaha. Menurut Sutardi, dkk menyatakan bahwa lingkungan keluarga berpengaruh positif terhadap hasil belajar. Hasil yang sama juga didapatkan dari penelitian, bahwa faktor lingkungan berpengaruh signifikan terhadap motivasi belajar taruna. Lingkungan keluarga memiliki pengaruh yang sangat besar terhadap 
motivasi belajar taruna. Banyak faktor yang dapat mempengaruhinya, antara lain cara orang tua mendidik, suasana rumah, relasi antar keluarga dan pengertian orang tua. Bila orang tua mendidik putra putrinya dengan baik dan benar, maka dapat berpengaruh positif terhadap motivasi yang terbentuk dalam diri pribadi taruna atau taruni. Suasana rumah yang kondusif juga menjadi faktor yang cukup penting dalam memberikan motivasi belajar bagi taruna taruni, suasana rumah yang tenang dan nyaman bisa meningkatkan motivasi belajar taruna. Relasi antar anggota keluarga dan pengertian orang tua tidak kalah penting perannya dalam meningkatkan motivasi belajar taruna. Orang tua yang selalu mendampingi taruna dalam pembelajaran daring, serta selalu mengingatkan agar tidak malas belajar, merupakan faktor yang penting dalam proses pembelajaran daring agar motivasi belajar tetap terjaga dengan baik. Di samping itu juga ada faktor keadaan ekonomi keluarga dan latar belakang budaya menjadi sangat penting ketika pelaksanaan pembelajaran daring. Dukungan orang tua dalam menyediakan fasilitas internet menjadi sangat penting ketika taruna melaksanakan pembelajaran daring. Bila penyediaan fasilitas internet terganggu, maka pembelajaran daring juga akan terganggu, sehingga motivasi belajar taruna juga akan menurun. Kebiasaan atau budaya dalam melaksanakan belajar di rumah juga sangat penting, misalnya belajar sambil menonton televisi, belajar sambil bermain HP atau belajar sambil tiduran. Hal tersebut sangat berpengaruh terhadap pelaksanaan pembelajaran daring yang dilaksanakan taruna taruni, sehingga akan berpengaruh juga terhadap Motivasi belajar taruna

\section{KESIMPULAN}

Pembelajaran Daring berpengaruh signifikan terhadap Motivasi Belajar Taruna. Ada beberapa faktor yang dapat mempengaruhi pembelajaran daring untuk meningkatkan motivasi belajar taruna, yaitu faktor teknis, proses pembelajaran dan dukungan kampus PIP Semarang dalam menyelenggarakan pembelajaran daring.

Faktor Lingkungan berpengaruh signifikan terhadap Motivasi Belajar Taruna. Beberapa faktor yang berpengaruh pada lingkungan keluarga yang dapat meningkatkan Motivasi Belajar Taruna, antara lain : Cara orang tua mendidik, relasi antar anggota keluarga, suasana rumah, keadaan ekonomi keluarga, pengertian orang tua dan latar belakang kebudayaan

\section{SARAN}

Saran dari penelitian ini adalah Pihak PIP Semarang diharapkan dapat terus mengembangkan sarana prasarana yang dapat mendukung pembelajaran daring bagi taruna taruni PIP Semarang. Sebagai contoh mengembangkan fasilitas e-Learning yang saat ini sedang digunakan untuk proses pembelajaran daring taruna taruni.

Dukungan keluarga bagi taruna taruni PIP Semarang sangatlah penting dalam proses pembelajaran daring, agar motivasi belajar taruna dapat meningkat. Orang tua diharapkan dapat mendukung pelaksanaan pembelajaran daring bagi taruna taruni dengan cara selalu berkoordinasi dan berkomunikasi dengan pihak kampus PIP Semarang apabila terjadi kendala dalam pelaksanaan pembelajaran daring

\section{DAFTAR PUSTAKA}

Alessandro, B. 2018. Digital Skills and Competence, and Digital and Online Learning. Turin: European Training Foundation.

Basri, Hasan. 2013. Landasan Pendidikan, Bandung: Pustaka Setia.

Cahyani, A. 2020. Motivasi Belajar Siswa SMA pada Pembelajaran Daring di Masa Pandemi Covid-19. Jurnal Pendidikan Islam, Volume 3 No. 01 2020, p. 123-140, ISSN: 2338-4131 (Print) 2715-4793 (Online).

Cresweel, J. W. 2016. Research Design: Pendekatan Kualitatif, Kuantitatif, dan Mixed. Yogyakarta: Pustaka Pelajar.

Damayanti R. 2011. Pengaruh Cara Belajar, Lingkungan Keluarga, Lingkungan Sekolah, Dan Motivasi Terhadap Hasil Belajar Mata Pelajaran Akuntansi Siswa Kelas Xi Ilmu Sosial Di Sma Negeri 8 Purworejo.

Fitriyani Y, dkk. 2016. Motivasi Belajar Mahasiswa Pada Pembelajaran Daring Selama Pandemik Covid-19. Jurnal Kependidikan, Juli 2020. Vol.6, No.2, e-ISSN: 2442-7667.

Jamil, S.H, dkk. 2020. Pengaruh Pembelajaran Daring Terhadap Minat Belajar Mahasiswa Pada Masa Pandemik Covid-19. Behavioral Accounting Journal, Vol. 3, No. 1, Juni 2020, e-ISSN: 26157004.

Khusniyah, N.L, dkk. 2019. Efektifitas Pembelajaran Berbasis Daring: Sebuah Bukti Pada Pembelajaran Bahasa Inggris, JURNAL TATSQIF, Jurnal Pemikiran dan Penelitian Pendidikan, Volume 17, No. 1, Juni 2019, P ISSN: 1829-5940, E ISSN: 2503-4510.

Kurniawan, A, dkk. 2016. Pengaruh Lingkungan Keluarga, Motivasi, Dan Kepribadian Terhadap Minat Wirausaha Melalui Self Efficacy

Mather, M., \& Sarkans, A. 2018. Student Perceptions of Online and Face-to-Face Learning. International Journal of Curriculum and Instruction, 10(2), 6176.

Mulyasa. 2013. Pengembangan dan Implementasi Kurikulum 2013, Bandung: Remaja Rosadakarya 
Mustofa, M. I., Chodzirin, M., Sayekti, L., \& Fauzan, R. 2019. Formulasi Model Perkuliahan Daring sebagai Upaya Menekan Disparitas Kualitas Perguruan Tinggi. Walisongo Journal of Information Technology, 1(2), 151. https://doi.org/10.21580/wjit.2019.1.2.4067.

Pratama, A, P. 2021. Pengaruh Pembelajaran Daring Terhadap Motivasi Belajar Siswa SD

Pratama, H. J., Ghofur, M. A. 2021. Pengaruh Motivasi Belajar dan Lingkungan Belajar Terhadap Hasil Belajar Mata Pelajaran Ekonomi Siswa Saat Pembelajaran Daring.

Puspitaningtyas N, D, dkk. 2020. Persepsi peserta didik terhadap pembelajaran berbasis daring, JPMI Volume 3, No. 6, November 2020, ISSN 26142155.

Sarahutu M, G. 2020. Pembelajaran online, minat belajar, dan kehidupan sehari-hari mahasiswa Pendidikan fisika Universitas Sanata Dharma di Tengah Covid-19.

Sugiyono. 2018. Metode Penelitian Kuantitatif, Kualitatif dan R\&D. Bandung: CV Alfabeta.
Sutardi, dkk. 2016. Pengaruh Kompetensi Guru, Motivasi Belajar, Dan Lingkungan Keluarga Terhadap Hasil Belajar Mata Pelajaran Ekonomi.

Suyono dan Hariyanto. 2011. Belajar dan Pembelajaran, Bandung: Remaja Rosadakarya.

Sujarweni, V. Wiratna. 2014. Metode Penelitian: Lengkap, Praktis, dan Mudah Dipahami. Yogyakarta: Pustaka Baru Press

Sur, W. A. A., Hasanah, M., \& Mustofa, M. R. (2020). Analisis Motivasi Belajar Mahasiswa dengan Sistem Pembelajaran Daring Selama Masa Pandemi Covid-19. Jurnal Equation: Teori dan Penelitian Pendidikan Matematika, 3(2), 157-171.

\section{UCAPAN TERIMA KASIH}

Terima kasih kami sampaikan kepada Unit Penelitian dan Pengabdian kepada masyarakat PIP Semarang atas dukungan dan kesempatannya dalam pelaksanaan Tri Dharma Perguruan Tinggi bagi Dosen khususnya bidang penelitian. 